Vol 1, No. 1 (2020), June 2020

E-ISSN: $2746-2471$

\title{
PENTINGNYA MANAJEMEN DIRI DALAM BERWIRAUSAHA
}

\author{
MASAYU ENDANG APRIYANTI \\ Program Studi Desain Komunikasi Visual \\ Fakultas Bahasa dan Seni Universitas Indraprasta PGRI \\ Email: masayuendangapriyanti@gmail.com
}

\begin{abstract}
Abstrak
Penelitian ini bertujuan mengetahui pentingnya manajemen diri dalam melakukan suatu usaha atau berwirausaha, karena dengan manajemen diri semua dapat dilaksanakan dengan baik sehingga pada akhirnya kesuksesan dapat diraih. Kelihatannya manajemen dirimudah untuk dikatakan, tapi dalam pelaksanaannya cukup sulit karena membutuhkan kesungguhan dan tekat yang kuat agar mampu berwirausaha dengan sukses.Metode penelitian dilakukan secara deskriptif yang bersifat survey langsung pada kelompok wirausahawan tertentu di wilayah Jakarta Barat, studi perpustakaan dan literatur. Hasil dari penelitian ini membuktikan bahwa manajemen diri sangat berperan terhadap kesuksesan berwirausaha
\end{abstract}

Kata kunci :Manajemen Diri, Berwirausaha 
Vol 1, No. 1 (2020), June 2020

E-ISSN: 2746-2471

\section{A. PENDAHULUAN}

Bahasan mengenai manajemen diri mungkin sudah beberapa kali atau mungkin sering kali kita dengar, banyak juga nasehat yang mengarahkan pada kita agar mampu memanajemen diri dengan baik agar semua urusan dapat diselesaikan tepat waktu dan tepat sasaran. Namun dalam praktek keseharian, terkadang sebagian dari kita mungkin kurang baik / kurang tepat dalam memanajemen diri sehingga tidak semua tujuan dan harapan yang ditargetkan dapat tercapai dengan optimal. Begitu juga para wirausaha, apalagi mereka yang masih tergolong pendatang baru dan wirausaha kecil-kecilan, sebenarnya kurang berhasilnya mereka dalam menjalankan usaha adalah karena kurang bagusnya mereka dalam memanajemen diri dengan baik sehingga operasional kegiatan tidak dapat terlaksana secara efektif dan effisien yang berdampak pada kesuksesan yang belum dapat diraih secara maksimal.

Manajemen diri yang baik adalah kondisi dimana kita mampu mengendalikan diri dalam mengatur dan mengekspresikan emosi, pikiran dan sikap, sehingga kita dapat mengelola stress, keegoisan, keakuan diri dan mampu memotivasi diri sendiri agar selalu melakukan yang terbaik dalam setiap aktivitas yang dilakukan demi meraih tujuan terbaik bagi diri sendiri, keluarga, maupun bagi perusahaan sehingga dapat menghadapi beragam rintangan yang menghadang dengan tenang dan kuat dalam melaluinya demi kesuksesan yang diharapkan.Kita harus yakin bahwa dengan manajemen diri yang baik dan penuh disiplin, maka apapun tujuan kita akan dapat diraih, karena selalu dimulai dengan perencanaan yang matang, pengorganisasian dan aksi yang jelas sampai pada pengontrolan yang dilakukan dengan kehati-hatian sehingga kesuksesan bukan hanya impian, tapi kenyataan yang akan segera diraih.

Jika mengacu pada konsep manajemen secara umum yang meliputi POAC yaitu Planning, Organizing, Actuating dan Controlling, maka manajemen diri adalah kemampuan kita sebagai individu dalam mempersiapkan segala perencanaan, mengatur detail susunan kegiatan yang akan kita lakukan, melaksanakan aksi yang tepat dan sesuai dengan perencanaan yang ditetapkan lalu mengontrol setiap kegiatan yang kita lakukan apakah sudah sangat sesuai dengan harapan atau masih banyak hal yang harus diperbaiki dan ditingkatkan kembali untuk langkah-langkah kita kedepan dalam mencapai suatu tujuan sesuai visi dan misi yang ada.

Porsi kemampuan seseorang menerapkan manajemen diri dalam kehidupannya pasti berbeda-beda yang tentunya dipengaruhi banyak hal dan faktor, diantaranya kebiasaan seseorang melaksanakan kedisiplinan di dalam lingkungan rumah / sekolah atau lingkungan sekitarnya, mungkin juga kekuatan tekat yang berasal dari dalam diri sendiri untuk mencapai tujuan hidup yang optimal karena dipengaruhi oleh pengalaman hidupnya atau pengalaman hidup dari lingkungan sekitarnya.

Manajemen diri yang baik pasti akan memberikan dampak positif yang signifikan bagi orang yang melakukannya, karena seluruh tugas dan kewajibannya diselesaikan dengan baik, semua masalah yang ada dapat dihadapi dengan solusi terbaik dan yang terpenting adalah semua mimpi, harapan dan usahanya, insya allah 


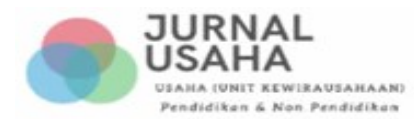

Vol 1, No. 1 (2020), June 2020

E-ISSN: 2746-2471

tidak ada yang gagal, atau andaikan sesekali harus gagal, maka itu adalah kegagalan yang memberikan ilmu, wawasan dan kesempatan yang lebih baik lagi untuk meraih sukses yang tertunda, karena allah swt pasti memberikan hasil terbaik sesuai dengan kerja dan usaha keras yang kita perjuangkan, dan yakinlah bahwa kerja keras yang kita perjuangkan, jika sudah tiba waktunya pasti akan memberikan hasil optimal seperti yang kita harapkan.

Pada umumnya tidak semua individu mampu memanajemen dirinya dengan efektif sehingga masih banyak yang belum meraih impian sesuai target yang diharapkan. Hal tersebut disebabkan oleh ketidakmampuannya dalam memanajemen diri dengan baik, karena sesungguhnya gagal atau berhasilnya seseorang dalam kehidupan, sangat mungkin salah satunya karena dipengaruhi oleh kemampuannya dalam menerapkan manajemen diri belum maksimal, maka itu sebaiknya kemampuan manajemen diri harus terus ditingkatkan seiring dengan usia dan kedewasaan cara pikir kita, sehingga semakin dewasa dan berpengalaman, maka semakin baik manajemen atas diri kita.

Karena itulah agar kita memiliki kemampuan memanajemen diri dengan baik, maka kita harus banyak belajar dan terus berusaha meningkatkan kualitas diri bisa dengan mengikuti pendidikan dan pelatihan pengembangan diri, melalui seminarseminar atau membaca buku-buku motivasi dan inspirasi dari orang-orang sukses yang terkenal. Memang tidak semua orang bersedia berwirausaha, karena pada umumnya banyak sekali dari kita yang ingin berada di zona aman dengan menikmati suasana bekerja untuk orang lain dengan penghasilan yang pasti atau cenderung tetap ditiap bulannya dan walaupun flat atau mungkin ada kenaikan pendapatan yang tidak begitu besar per periodenya, atau mungkin juga banyak yang tidak tertarik berwirausaha karena tidak berani mengambil resiko. Namun terlepas dari alasan tersebut, siapapun yang memutuskan berwirausaha, berarti mereka para wirausahawan tersebut adalah orang yang berani mengambil resiko atas keputusannya, sejatinya mereka akan memiliki kesempatan lebih besar untuk berhasil secara optimal daripada orang-orang yang bekerja untuk orang lain, tapi tentunya keberhasilan mereka tidak mudah untuk diraih, mereka harus sungguh-sungguh bekerja keras dalam menjalankan usaha dan salah satunya mereka harus mulai dengan kemampuan memanajemen diri dengan sangat baik sehingga usaha yang dijalankannya lancar dan membuahkan hasil pencapaian tujuan / target secara optimal.

\section{B. KAJIAN PUSTAKA}

Demi waktu, sesungguhnya manusia itu benar-benar dalam kerugian, kecuali orang-orang yang beriman dan mengerjakan amal sholih dan nasehat menasehati supaya mentaati kebenaran dan kesabaran (QS. Al-Asr (103) : 1-3 ). Dari firman Allah SWT pada ayat ini, sebenanrnya manusia semua dalam keadaan rugi jika tidak dapat memanfaatkan waktu dengan baik, nah ini erat kaitannya dengan kemampuan manajemen diri sendiri, bagi orang-orang yang mampu memanajemen diri dengan baik, maka ia akan memanfaatkan waktu yang ada sebaik mungkin, ia akan beramal 


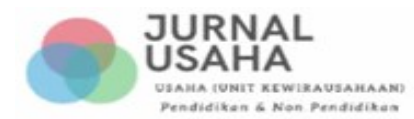

Vol 1, No. 1 (2020), June 2020

E-ISSN: 2746-2471

sholih dan akan mengisi seluruh kegiatannya dengan segala aktivitas yang positif dan bermanfaat sehingga seluruh hidupnya digunakan untuk sesuatu yang bermanfaat dan ia akan meraih sukses dunia dan akhirat.

Manajemen diri merupakan pengendalian diri terhadap pikiran, ucapan, dan perbuatan yang dilakukan, sehingga mendorong pada penghindaran diri terhadap halhal yang tidak baik dan peningkatan perbuatan yang baik dan benar. Manajemen diri adalah sebuah proses merubah "totalitas diri" baik itu dari segi intelektual, emosional, spiritual dan fisik agar apa yang kita inginkan (sasaran) tercapai (Asmi Afdilla, 2016. https://www.dictio.id/t/bagaimana-caranya-untuk-mengelola-diri-sendiri-dengan$\underline{\text { baik/1313) }}$

Seseorang dapat dikatakan mampu mengendalikan dirinya dengan baik, jika ia mampu mengatur sikap, perbuatan dan segala langkah keputusannya dengan sangat baik, sehingga dapat dipastikan bahwa kelak ia akan menjadi pribadi yang sukses dalam kehidupannya. Demikian juga dalam keseharian, kita dapat melihat dan menganalisa bahwa jika seseorang selalu memanajemen diri dengan baik, maka semua kegiatan, tugas dan tanggung jawabnya dapat dilaksanakan sepenuh hati dan seoptimal mungkin, yang terwujud dari penyelesaian tugas dengan baik, tepat waktu, hasil maksimal sesuai tujuan dan harapan, tidak ada yang merasa kecewa bekerjasama dengannya, karena ia tidak suka menunda-nunda waktu atau membuang waktu dengan percuma sehingga ia sangat fokus dalam menjalani kehidupan ini dimulai dari manajemen diri yang baik.

Wiraswasta (Wirausaha) adalah usaha-usaha yang mempunyai keunggulan tertentu untuk memodifikasi produk lama menjadi produk baru, dengan menciptakan lapangan pekerjaan, yang memanfaatkan pemberdayaan manusia dan kekayaan alam lainnya (Robert Argene, 2003 : 1). Dari pengertian ini, Kita dapat artikan berwirausaha adalah seseorang atau sekelompok orang yang melakukan kegiatan usaha dengan segenap kemampuannya dalam menggunakan kesempatan / peluang yang ada, dengan berusaha melakukan fungsi manajemen sebaik-baiknya untuk kelancaran operasional usahanya dalam menghadapi resiko yang pasti ada untuk mencapai tujuan bersama dan meraih keuntungan dari usaha yang dilakukannya.

Untuk menjadi wirausaha harus memiliki tekat yang bulat dan motivasi yang kuat, juga kemampuan manajemen diri yang baik agar usaha yang dijalankannya dapat berhasil maksimal, karena jika tidak memiliki manajemen diri yang baik, maka hidupnya tidak terarah dan usaha apapun akan menuju kegagalan.

Tidak ada manusia yang berhasil meraih sukses tanpa kerja keras, hidup ini sendiri adalah perjuangan (Freddy rangkuti , 2015 : 159). Dan Menurut berbagai penelitian, bekerja berdasarkan tujuan dan target akan memberikan hasil yang jauh lebih besar dan luar biasa dibandingkan dengan bekerja tanpa tujuan, apalagi tanpa target (Freddy Rangkuti, 2015 : 25-26). Artinya tidak ada kesuksesan yang didapat secara Cuma-Cuma, karena pada umumnya semua didapatkan dari hasil jerih payah dan kerja keras yang sudah diperjuangkan dalam kurun waktu yang tidak sekejap.

Hukum motivasi adalah segala sesuatu yang anda lakukan atau katakan dipicu oleh keinginan, poros penggerak dan naluri dari dalam diri anda, hal ini mungkin 


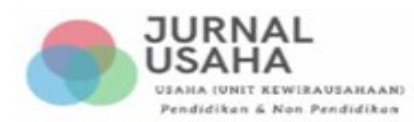

Vol 1, No. 1 (2020), June 2020

E-ISSN: 2746-2471

disadari atau tidak disadari (Brian Tracy, 2002 : 7). Dari kalimat tersebut yang penulis kutip, semua mengarah pada kesuksesan yang hanya dapat diraih jika kita memiliki tujuan pasti, yang diawali dengan manajemen diri yang baik.

Dan dapat disimpulkan dari beberapa teori sumber kutipan diatas, bahwa manajemen diri yang baik sangat luas cakupannya antara lain meliputi : (1). kemampuan diri dalam mengendalikan emosi, keegoisan, keakuan dan kemauan menang sendiri. (2). Kemampuan bersikap jujur, terbuka dan selalu dapat dipercaya disetiap situasi karena yang bersangkutan menjunjung tinggi kejujuran diatas segalanya, tidak ada yang disembunyikan yang dapat merugikan atau membuat kecewa orang yang bekerjasama dengan kita dan memegang teguh komitmen juga semua janji yang diucapkan. (3).Mampu beradaptasi dengan keadaan lingkungan yang dimasukinya namun tetap memegang kuat prinsipnya (4) . Mampu berinovasi dan mengimbangi perkembangan zaman maupun tuntutan keadaan (tuntutan profesi) tapi tetap dalam kondisi sesuai hukum yang berlaku (5). Selalu berhati-hati dalam menentukan keputusan atau suatu pilihan dan menjaga diri dengan baik dari hal yang sia-sia atau tidak memberi manfaat sehingga apapun usaha yang dijalankannya selalu memberikan kebaikan dan manfaat untuk banyak pihak (6). Setia pada visi dan misi yang sudah ditetapkan, sehingga ia tidak mudah terpengaruh dengan hal yang tidak baik dan tidak mudah juga terombang ambing karena memiliki visi misi yang kuat dan tujuan yang pasti disetiap keputusannya. (7). Pantang menyerah dan sangat gigih dalam menghadapi ujian dan rintangan apapun dalam berusaha menggapai tujuan yang diharapkan.

Seseorang yang berusaha dengan gigih, pasti akan mendapatkan hasil (Antoni Ludfi Arifin dan Sari Rahma Yulianthi, 2015 : 63). Dari kutipan ini dapat diartikan bahwa hasil akan diraih sesuai dengan kegigihan kita, semakin gigih maka semakin berhasil. Nah, kegigihan ini dapat kita landasi mulai dari kemampuan manajemen diri yang baik untuk segala keputusan yang kita ambil dan aktivitas yang akan kita lakukan.

Wirausaha adalah orang yang melihat adanya peluang kemudian menciptakan suatu organisasi untuk memanfaatkan peluang tersebut (Buchari Alma, 2004 : 21). Jika kita memiliki bakat untuk melihat peluang, maka sebaiknya berwirausahalah, karena sejatinya orang yang berwirausaha lebih banyak menebar kebaikan bagi banyak orang, karena yang dia lakukan bukan hanya untuk dirinya saja, melainkan untuk banyak karyawan yang dipimpinnya, untuk kelangsungan hidup perusahaannya, juga ikut berusaha mengentaskan kemiskinan di negara kita ini dengan berkarya dan memberi kesempatan bagi banyak individu untuk bekerja dan berkarya melalui usaha yang dimilikinya.

\section{METODE PENELITIAN}

Penelitian ini menggunakan pendekatan kualitatifdengan metode deskritif yang bersifat mempelajari kejadian dilapanganyang memungkinkan untuk melakukan hubungan antar variabel, menguji hipotesis, mengembangkan generalisasi, dan mengembangkan teori yang memiliki validitas universal. Metode 


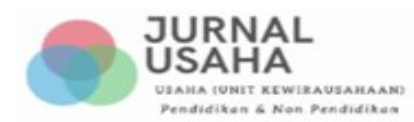

Vol 1, No. 1 (2020), June 2020

E-ISSN: 2746-2471

deskriptif adalah suatu metode dalam meneliti status sekelompok manusia, objek, kondisi, sistem pemikiran ataupun suatu kelas peristiwa pada masa sekarang. Tujuan dari penelitian deskritif ini adalah untuk membuat deskripsi, gambaran atau lukisan secara sistematis, faktual dan akurat mengenai fakta, sifat serta hubungan antar fenomena yang diselidiki ( Sugiyono, 2007 : 11 ). Beberapa fenomena yang dilihat hubungannya adalah pentingnya manajemen diri dalam berwirausaha. Metode pengumpulan data dalam penelitian ini adalah dengan mewawancarai beberapa wirausaha yang bergerak dibeberapa usaha, studi perpustakaan dan literatur.Penelitian berlangsung sekitar 4 bulan yaitu di akhir tahun, November 2019 sampai Februari 2020, mulai dari pengumpulan data dari studi perpustakaan dan literature sampai pada wawancara langsung pada beberapa wirausaha yang bergerak dibidang berbeda, ada yang bergerak dibidang kuliner, bergerak dibidang peralatan sparepart mobil dan motor, bergerak dibidang otomotif, bergerak dibidang layanan jasa kecantikan dan dibidang layanan jasa pengiriman yang berada diwilayah sekitar Jakarta Barat dan Tangerang.

\section{HASIL DAN PEMBAHASAN}

Hidup adalah pilihan, dan kesuksesan atau kegagalan sesungguhnya adalahsalah satu pilihan, karena jika kita ingin sukses maka sudah seharusnya kita berusaha keras untuk meraihnya, dimulai sejak dini dengan motivasi dan terus belajar yang kuat untuk meraih kesuksesan, karena kesuksesan itu harus diperjuangkan untuk diraih, begitu juga dalam hal berwirausaha, pasti setiap wirausaha mengharapkan kesuksesan atas usaha yang dijalankannya bahkan jika memungkinkan usahanya bukan hanya mampu bertahan saja melainkan harus bisa terus berkembang secara luas dan go internasional.

Manajemen diri adalah salah satu kunci penting bagi kita untuk meraih kesuksesan dalam hidup ini. Bagi wirausahawan, maka manajemen diri yang harus dilakukan sebaiknya difokuskan bukan hanya untuk dirisendiri tapi juga untuk perusahaan yang dipimpinnya dan segenap karyawan yang terlibat didalamnya.

Sesuaikan tujuan yang ingin anda capai dengan usaha yang anda lakukan. Ukuran tujuan kita sendiri yang mengetahuinya, apabila terlalu tinggi kita pasti akan memperoleh kegagalan, sebaliknya apabila target tujuan terlalu rendah, pasti tidak menantang, jadi penetapan target tujuan harus cukup menantang, tetapi realistis atau dapat dicapai (Freddy Rangkuti , 2015 : 36). Dari kutipan tersebut menunjukkan bahwa siapapun kita dapat meraih tujuan sesuai usaha yang kita lakukan, demikian juga para wirausahawan, mereka semua dapat sukses jika memiliki tujuan yang pasti dan usaha keras yang dilakukannya untuk meraih tujuan dan semua tujuan tersebut hanya dapat diraih jika diawali dengan usaha kita agar memiliki kemampuan memanajemen diri dengan baik.

Dari beberapa wirausaha yang penulis amati, keberhasilan yang mereka raih bukanlah dalam waktu singkat dan mudah, melainkan segalanya harus dengan kesungguhan dan kegigihan dalam perjuangan memanajemen diri sebaik mungkin hingga mampu meraih target yang diharapkannya dan seiring waktu berjalan, 


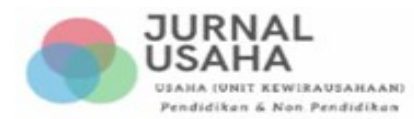

Vol 1, No. 1 (2020), June 2020

E-ISSN: 2746-2471

kesuksesan pun bukan hanya mimpi melainkan benar-benar dapat diraihnya dengan rasa kepuasan yang tidak dapat diungkapkan dengan kata-kata. Jika kita mampu terapkan manajemen diri dengan sangat baik secara comprehensive maka, Insya Allah, dengan izinNya seluruh usaha yang kita jalankan dapat beroperasional dengan baik, lancar dan bermanfaat serta seluruh tujuan yang ditetapkan dapat diraih sesuai target yang ada.

Seorang pengusaha seharusnya memiliki sifat-sifat berikut : 1 . Confidence : Percaya diri , dengan kepercayaan diri anda dapat memprioritaskan diri menjadi bisa / sanggup dalam menjalani setiap usaha tanpa merasa malu untuk memulainya dari kecil (awal). 2. Energi : Semangat / Tenaga / Kekuatan, Kita mempunyai potensi kekuatan diri lebih besar, apabila dikembangkan dan dilatih 3. Ability to take calculated risk : mengkalkulasi resiko yang akan terjadi dimana kecermatan, ketelitian, kehati-hatian merupakan sikap yang harus dimiliki dari seorang wirausahawan karena penggabungan dari kesemuanya ini adalah memfokuskan kepada dampak yang akan terjadi setelah usaha dijalankan. 4. Dinamism : Melakukan perubahan / cara dalam penentuan lokasi usaha, Seorang wirausahawan harus dapat melihat dan memilih tempat yang strategis untuk usaha yang akan dijalankannya sehingga dapat kemajuan yang pesat. 5. Leadership ; mempunyai sifat memimpin, dimana jiwa pemimpin merupakan hal vital bagi wirausahawan untuk dikembangkan 6. Optimism 7. Need to achieve ; kemampuan untuk mencapai target 8. Kreatif 9. Fleksibel 10. Rasa Tanggung jawab 11. Independen 12. Inisiatif (Robert Argene, $2003: 3-8)$.

Tulisan Argene yang saya kutip diatas, mengenai sifat yang harus dimiliki oleh wirausaha mencerminkan bahwa sifat-sifat tersebut dapat diterapkan dengan baik sesuai dengan kemampuan manajemen dirinya. Dan jika wirausaha tersebut dapat memanajemen diri dengan sangat baik, insyaallah ia akan meraih kesuksesan dalam menjalankan usahanya. Salah satu contoh, Misalkan saja pada poin nomor 7 tentang kemampuan untuk mencapai target, maka dengan manajemen diri yang tepat dalam membuat perencanaan dan menentukan keputusan tentunya akan sangat berpengaruh terhadap pencapaian target yang ditetapkan.Manajemen diri yang baik bukan hanya mengantarkan pada pencapaian target saja, melainkan juga dapat memberikan sikap saling menghargai sesama dan memberikan pencitraan tersendiri bagi personal tersebut, contohnya rasa percaya diri dalam menjalankan usahanya dapat merealisasikan suatu tujuan yang awalnya baru berupa impian / harapan lalu bisa menjadi kenyataan yang membanggakan.

Berwirausaha berarti kegiatan usaha yang dilakukan oleh para wirausaha dalam berbagai jenis usaha apapun. Hukum Kewirausahaan ; Jalan pasti menuju kaya adalah memulai dan membangun sebuah bisnis anda sendiri yang berhasil, tidak pernah ada orang yang menjadi kaya dengan bekerja untuk orang lain (Brian Tracy, 2002 : 77). Artinya jika seseorang ingin benar-benar sukses dan kaya raya, maka yang harus dilakukan adalah jangan puas berada di zona aman menjadi karyawan, tapi ia harus berani berada pada zona yang beresiko dan mampu menjadi wirausaha yang tangguh menghadapi rintangan dan ketatnya persaingan untuk meraih sukses secara 


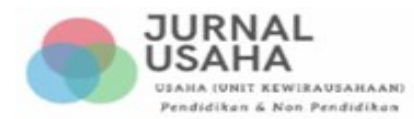

Vol 1, No. 1 (2020), June 2020

E-ISSN: 2746-2471

optimal maka ia akan meraih kepuasan dalam banyak hal, salah satunya kepuasan akan kekayaan atau keuntungan yang didapatkannya.

Berwirausaha itu gampang-gampang susah, dimana jika dijalani dengan sungguh-sungguh dan ikhlas maka seberat apapun beban akan berasa ringan dan dapat dijalani dengan penuh suka cita, namun jika dipikir berat dan rumit, maka ia tidak akan meraih sukses dalam berwirausaha.Karena itulah, untuk menjadi pengusaha atau wirausaha yang sukses sebaiknya benar-benar dipersiapkan dengan matang dan kebulatan tekat, jangan hanya sebagai pelarian saja, karena awal niat akan mempengaruhi hasil yang akan diraih.

Mentalitas wirausaha ditandai dari adanya semangat berprestasi dan kejelian menangkap serta menciptakan peluang untuk menghasilkan sesuatu yang lebih baik (Eileen Rachman, 2016 :457). Berarti jika kita selalu bersemangat untuk berprestasi dan jeli menangkap peluang, maka sesungguhnya kita memiliki mental wirausaha dan kita juga berpeluang untuk meraih kesuksesan jika kita pandai memanajemen diri secara optimal. Semakin tinggi semangat untuk berprestasi dan semangat untuk selalu berkarya maka akan semakin tinggi peluang keberhasilan yang mungkin dapat diraih.

kepemimpinan dimulai dengan individu masing-masing. Kepemimpinan pribadi adalah tentang manajemen diri. Anda bisa memulai dari diri Anda, sehingga Anda dapat memimpin orang lain secara efektif. (Pranala Magni Daya,www.pranalatraining.co.id). Dari kutipan artikel Pranala tersebut, kita dapat mencoba untuk introspeksi diri kita masing-masing, sudah sanggupkah kita memanajemen diri dengan baik, karena selama ini jika kita telah mampu memanajemen diri dengan baik, artinya kita sanggup mengatur dan mengendalikan diri kita dalam menjalankan semua aktivitas termasuk dalam hal memilih dan menentukan skala prioritas yang harus dikerjakan, mampu mengendalikan emosi dalam segala sesuatu, mampu memanfaatkan waktu dengan efektif dan effisien, mampu melaksanakan segala hal sesuai visi dan misi yang ditetapkan juga mampu mencari solusi terbaik disetiap tantangan yang dihadapi, maka insyaallah kita akan mampu menjadi pemimpin yang baik (dalam hal ini, kita mampu menjadi wirausaha / berwirausaha dengan baik, karena kita akan mampu memimpin dan mengendalikan anak buah dan perusahaan yang kita pimpin), dan memang semua diawali mulai dari diri kita sendiri, semakin tinggi kemampuan manajemen diri dengan baik, maka yang bersangkutan juga akan mampu memanajemen orang lain, memanajemen organisasi dan sebagainya dengan baik, yang semuanya akan mempengaruhi keberhasilan yang didapatnya kelak.

Manajemen diri adalah bagaimana individu mengatur dan mengelola diri sendiri dalam hal yang berkaitan dengan pemenuhan kebutuhan, waktu dan pencapaian tujuan diri (Juriana, 2000). Manajemen diri sangat dibutuhkan oleh seseorang, terutama para generasi muda yang merupakan tumpuan harapan bangsa. Manajemen diri dapat menentukan kesuksesan seseorang dalam melakukan usaha untuk membangun dirinya (Peter Agung, 2017. www.floressmart.com.2017/02/01)

Dari kalimat diatas, kita dapat katakan bahwa manajemen diri sangat berperan penting terhadap keberhasilan seseorang dan perusahaan / lembaga yang 


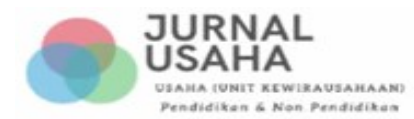

Vol 1, No. 1 (2020), June 2020

E-ISSN: 2746-2471

dipimpinnya. Semakin baik manajemen dirinya, maka kesuksesan diri dan apapun yang dikelola dan dipimpinnya akan optimal diraih sesuai dengan harapan dan target yang ditetapkan secara efektif dan efisien.Dengan manajemen diri yang baik pula, maka seseorang akan terus berusaha menjadi pribadi yang lebih baik, sangat menghargai waktu dan melaksanakan semua aktivitas sesuai ketetapan (schedule) yang sudah disepakati, sehingga dengan manajemen diri yang baik pada setiap individu, maka : 1. Semakin hari ia akan semakin mampu mengendalikan diri dengan baik, mengelola waktu dengan efektif, perubahan kedewasaan, pola pikir, sikap dan tingkah laku yang semakin bijak dan berkualitas juga memiliki strategi yang lebih baik dan santun baik internal maupun eksternal. 2. Dengan membiasakan manajemen diri secara tepat maka ia merasakan manfaat positif disetiap aktivitasnya, kelancaran disetiap urusannya dan kemudahan dalam pencapaian setiap target / sasarannya, sehingga memberikan pengalaman positif dan tekat yang lebih kuat lagi dalam pelaksanaan manajemen diri yang semakin efektif efisien dan berkualitas. 3 . Manajemen diri yang baik akan terus memotivasi individu untuk selalu memanfaatkan waktu, tenaga dan fikiran secara optimal sehingga dapat menebar banyak manfaat dan kebaikan secara penuh serta mampu menciptakan karya-karya berkualitas.

Sejatinya untuk memulai memanajemen diri sendiri itu lebih sulit dibandingkan memanajemen orang lain atau benda-benda lain, karena manajemen diri terdiri dari cukup banyak aspeknya, diantaranya kemampuan memanajemen emosinya, perasaannya, keinginannya, keluasan fikiran, egonya, fleksibilitas, dan integritas, sehingga berdasarkan observasi terhadap beberapa perusahaan yang saya amati, kunci kesuksesan mereka adalah manajemen diri yang baik, karena manajemen diri mempengaruhi banyak memberikan hal baik, yaitu :1. Mendorong diri sendiri agar lebih termotivasi untuk mencapai tujuan, 2. Meningkatkan kendali diri yang kuat dan tidak tergantung atau mudah terpengaruh oleh siapapun. 3. Dengan Tekad kuat, akan mudah mencapai target yang kita harapkan 4. Dengan manajemen diri arah tujuan hidup lebih pasti. 5. Gigih menghadapi kehidupan dengan terus berusaha menjadi yang terbaik sesuai kemampuan masing-masing. 6. Tidak akan membuang waktu percuma untuk hal yang tidak bermanfaat / sia-sia.

Dari artikel di Internet, Penulis ambil contoh beberapa pengusaha atau wirausaha sukses yang ada di Indonesia sampai saat ini, mereka adalah Ahmad Zaky Seorang founder dan CEO buka lapak, dimana berkat ketertarikannya pada dunia informatika sejak duduk di bangku SD, kegigihannya kini membuahkan hasil yang mengantarnya menjadi wirausahawan sukses. Lambat laun, berkat ketekunan sang pemilik yang lahir di tanggal 24 Agustus 1986 (32 tahun), BukaLapak.com mulai dikenal dan menerima banyak investasi dari dalam negeri maupun luar negeri, ada juga sosok William Tanuwijaya merupakan pendiri situs jual-beli Tokopedia.com. Pria kelahiran 11 November 1981 (37 tahun) ini adalah seorang anak daerah yang merantau ke ibukota setelah lulus SMA dan meneruskan pendidikan sarjananya di Jakarta. Langkah William menjadi pengusaha sukses ini tidaklah mudah. Ia bahkan pernah menjadi penjaga warnet untuk bisa mendapatkan uang tambahan. Dari 


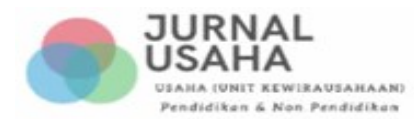

Vol 1, No. 1 (2020), June 2020

E-ISSN: 2746-2471

menjaga warnet inilah, dia mengenal dunia internet secara lebih dalam. Setelah menjadi penjaga warnet, William bekerja di beberapa perusahaan software dan game developer. Dari berbagai macam pengalamannya inilah, ia kemudian merintis Tokopedia.com pada tahun 2009. (www.liputan6.com).

Dan dari contoh pengusaha yang penulis ambil diatas, dimana mereka sampai saat ini merupakan pengusaha sukses di Indonesia dan usahanya masih menjadi favorit dikalangan masyarakat, dan perjuangan mereka meraih sukses tidaklah semudah membalikkan telapak tangan, karena mereka melakukan perjuangan dan usaha yang keras untuk meraih sukses saat ini dan semua itu dapat diraih secara optimal, dan salah satu faktor yang mendukung kesuksesan mereka adalah kemampuan memanajemen diri dengan baik yang didalamnya tentu mencakup kegigihan diri dalam menjalankan suatu keputusan yang dipilihnya, kekuatan dan kesabaran dalam menjalankan sesuatu, serta kemampuan untuk terus teguh berjuang sampai tujuan tersebut dapat dicapai sesuai tujuan yang diharapkan.

\section{E. SIMPULAN}

Persaingan dunia usaha yang semakin ketat, dengan dinamika kehidupan yang semakin beragam dan persaingan mendapat kehidupan layak yang semakin menantang, seharusnya mendorong kita untuk melakukan yang terbaik dari sumber daya yang kita miliki atau yang ada di sekitar kita, sehingga kita mampu memanajemen diri secara maksimal untuk tujuan yang ingin kita raih. Sehingga sudah seharusnya setiap individu mampu memanajemen diri dengan baik untuk meraih kehidupan yang lebih layak dan berkualitas. Karena sejatinya manajemen diri sangat berperan dalam mempengaruhi perjalanan hidup dan kesuksesan yang dapat dicapai oleh seseorang maupun sekelompok orang tertentu sesuai dengan harapan dan tujuan yang ditargetkan.

Dalam hal peningkatan kemampuan manajemen diri yang baik, banyak pihak yang harus bekerjasama dalam hal mewujudkan peningkatan kualitas sumber daya manusia, diantaranya yaitu pemerintah dengan memberikan pembinaan, para orang tua dan guru / pendidik melalui keteladanan yang baik, seluruh karyawan terkait harus focus mengatur manajemen diri dalam beraktivitas sehari-hari secara optimal sehingga mampu mendukung keberhasilan perusahaan secara maksimal dan para pemilik / Boss, bisa melalui pemberian pelatihan atau bimbingan pada anak buahnya, agar paham menyeluruh tentang pentingnya manajemen diri dan manfaatnya dalam keseharian, yang diawali dari Setiap orang tua agar membimbing anak-anaknya sejak dini belajar mengenal dan menerapkan manajemen diri dalam keseharian agar dapat meraih masa depan yang gemilang. 


\section{DAFTAR PUSTAKA}

Alqur'an al karim

Sugiyono, (2007), "Metode Penelitian Pendidikan, Pendekatan Kuantitatif, kualitatif dan R\&D”, Bandung, Alphabeta.

Argene. R. (2003). “Strategi menjadi wiraswasta Handal”, Jakarta. CV. Restu Agung.

Tracy. B (2002). “Prinsip Sukses Universal” Jakarta, KDT. PT. Pustaka Delapratasa Publishing.

Rangkuti. F, (2015). "Personal SWOT Analysis". Jakarta: PT Gramedia Pusataka Utama.

Arifin A. L \& Yulianthi S.R. (2015). “Building Personal Brand Equity”. Jakarta. PT. Gramedia Pustaka Utama

Rachman. E. (2016). “Sukses Mawas Diri”. Jakarta. PT. Gramedia Pustaka Utama

Daya P. M, (2018). “Kepemimpinan Pribadi - Pentingnya Manajemen Diri”, Pranala Training, 14 sept 2018, www.pranalatraining.co.id

Agung.P. (2017). "Pentingnya Manajemen Diri Bagi Calon Mahasiswa”. 1 Februari 2017. www.floressmart.com.2017/02/01

Afdilla. A, (2016). "Bagaimana caranya mengelola diri sendiri dengan baik”, 01 Oktober 2016. https://www.dictio.id/t/bagaimana-caranya-untuk-mengelola-dirisendiri-dengan-baik/1313

Sari. M. S, (2018). "7 Pengusaha Muda Indonesia yang Menginspirasi Generasi Milenial, siapa saja?", $09 \quad$ Desember 2018. https:/www.liputan6.com/bisnis/read/3801903/7-pengusaha-muda-indonesia-yangmenginspirasi-generasi-milenial-siapa-saja 